\title{
PERSEPSI KEADILAN KOMPENSASI TERHADAP KOMITMEN ORGANISASIONAL MELALUI KEPUASAN KERJA
}

\author{
Wilujeng Rahayu \\ PT. PG Rajawali I Unit I Krebet Baru Bululawang, Malang \\ E-mail: Wilujeng_Rahayu24@yahoo.com
}

\begin{abstract}
Fairness has an important relationship to the concept of commitment, but has only received little attention in the Human Resources Management literature. Basic question about the relationship between fairness and organizational commitment are whether there is a variable between these to constructs or whether there is direct influence. Previous literature has revealed mixed results. Locke Luthan (1990) state that the relationship of fairness in the form of an award contingent and non contingent on organizational commitment through job satisfaction. The goal of this research is to test and prove that perception of fairness compensation affect on organizational commitment through job satisfaction. The research was conducted at PT. PG Rajawali I Krebet Baru Bululawang, Malang.

There the entire employee population is fixed and using random sampling techniques the study obtained 358 respondents. Three variables are collected using questionnaires and interviews: the perception of compensation's fairness, organizational commitment and job satisfaction. The data is analyzed using path analysis and regression. The results show that perception of compensation fairness has a positive and significant impact on organizational commitment and a significant positive effect on job satisfaction. Job satisfaction has positive and significant impact on organizational commitment. Perception of compensation fairness has a stronger influence on organizational commitment if the relationship is direct rather than the indirect influence job satisfaction as a mediating variable. From the results of indirect influence perception of compensation fairness to the commitment through satisfaction can be interpreted that the employee reminds not imported level of job satisfaction, but employees feel that fair compensation from the company will further enhance employee commitment to the organization.
\end{abstract}

Keywords: compensation fairness perceptions, job satisfaction, organizational commitment.

\section{PENDAHULUAN}

Salah satu aspek yang penting untuk diperhatikan oleh perusahaan atau organisasi terkait dengan peran sumber daya manusia adalah masalah keadilan kompensasi. Khususnya keadilan kompensasi telah menjadi isu sentral yang banyak dibahas dalam berbagai literature sumber daya manusia (Suhartini, 1999).Hal ini dikarenakan masalah keadilan kompensasi akan berhubungan dengan kemampuan karyawan untuk memenuhi segala kebutuhan hidupnya sehari-hari. Selain itu, masalah keadilan kompensasi juga mengindikasikan kebijakan perusahaan atau organisasi dalam memperlakukan para karyawannya secara adil.
Penelitian Sudarwati (2007) dalam analisis pengaruh keadilan kompensasi, peran kepemimpinan, dan kepuasan kerja terhadap komitmen organisasi dalam meningkatkan kinerja karyawan membuktikan bahwa ada pengaruh yang searah antara keadilan kompensasi dengan komitmen organisasional. Hal ini mendukung penelitian Babakus, et al (1993) meneliti pengaruh keadilan kompensasi terhadap komitmen organisasional, hasilnya menunjukkan adanya hubungan signifikan antara keadilan kompensasi dengan komitmen organisasional.

Besarnya imbalan finansial atau kompensasi yang diterima karyawan dapat mempengaruhi per- 
sepsi karyawan terhadap kompensasi, yaitu apakah kompensasi dipersepsikan adil atau tidak. Persepsi dipengaruhi oleh kebutuhan, pengalaman, suasana emosional, kesiapan mental, dan latar belakang budaya (Rakhmat, 1998). Faktor-faktor yang mempengaruhi persepsi tersebut mengakibatkan persepsi seseorang terhadap objek yang sama dapat berbeda-beda.

Karyawan akan memiliki persepsi terhadap keadilan kompensasi yang positif apabila rasio input dan output seimbang sehingga akan memiliki kepuasan kerja yang bagus. Apabila imbalan yang diterima karyawan dipersepsikan terlalu besar atau terlalu kecil makakaryawan akan memiliki persepsi terhadap keadilan kompensasi yang negatif sehingga bisa mengalami distres atau ketidakpuasan. Selain perbandingan antara input dan output seimbang (keadilan internal), perbandingan imbalan yang wajar atau sesuai dengan karyawan lain yang mempunyai pekerjaan yang sama juga mempengaruhi kepuasan kerja (keadilan eksternal) (Witt \& Nye, 1992).

Inverson dan Roy (1994 dalam Roberts Coulson 1999) yang menguji model lisrel yang menghubungkan antara keadilan pembayaran melalui kepuasan kerja yang bisa membangun komitmen organisasional dan memperkecil tingkat turnover. Hasil penelitiannya tidak menemukan hubungan antara keadilan dan kepuasan kerja. Disamping itu persepsi keadilan dapat menciptakan komitmen dan mengurangi tingkat turnover. Hal ini kemudian keadilan dihubungkan langsung terhadap komitmen organisasional. Mereka merasa bahwa karyawan yang merasakan diperlakukan secara adil maka akan diidentifikasikan dan terlibat dalam organisasi sehingga mempunyai loyalitas tinggi terhadap organisasi.

Keadilan mempunyai hubungan penting terhadap konsep dari komitmen tetapi hanya menerima sedikit perhatian dalam literatur manajememen sumber daya manusia, pertanyaan dasar mengenai hubungan antara keadilan dan komitmen organisasional apakah ada variabel moderator antara dua konstruk tersebut atau apakah pengarunya langsung. Literatur-literatur telah mencampuradukkan hasilnya, tetapi bobot pembuktiannya terlihat se- bagai pembuktian yang langsung. Locke dan Luthan (1990) menyatakan bahwa hubungan keadilan dalam bentuk penghargaan kontingen-dan non kontingen terhadap komitmen organisasional melalui kepuasan kerja.

\section{TINJAUANPUSTAKA}

Walgito (2002), persepsi merupakan suatu proses yang didahului oleh proses penginderaan terhadap suatu stimulus yang kemudian diorganisasikan dan diinterpretasikan oleh individu, sehingga individu menyadari, mengerti tentang apa yang diindera tersebut. Menurut Suhartini (1999) keadilan kompensasi dapat dibedakan menjadi 3 diantaranya adalah sebagai berikut: 1) Keadilan Individu, seorang manajer dituntut memiliki pemahaman bahwa karyawan merupakan sumber daya utama dan penting serta bahwa semua karyawan memiliki peluang untuk menggunakan bakat dan kemampuan mereka untuk mendapat keuntungan tertentu bagi diri mereka sendiri maupun bagi organisasi. 2) Keadilan internal, merupakan suatu kriteria keadilan dari kompensasi yang diterima karyawan dari pekerjaannya dikaitkan dengan nilai internal masing-masing pekerjaan.Keadilan internal juga mengidentifikasikan bahwa posisi yang lebih disukai atau karyawan dengan kualifikasi lebih tinggi dalam perusahaan haruslah diberi kompensasi yang lebih tinggi pula (Smith, 1990). 3) Keadilan eksternal atau sering disebut daya saing eksternal, merupakan posisi kompensasi yang diberikan oleh suatu organisasi terhadap seorang karyawan dibandingkan dengan kompensasi yang diberikan oleh perusahaan pesaing, tentunya untuk seorang karyawan dengan suatu pekerjaan yang bernilai sama.

Aspek-aspek persepsi terhadap keadilan kompensasi yang digunakan dalam penelitian ini adalah aspek-aspek persepsi yang dikemukakan oleh Branca, Woodworth, \& Marquis (dalam Walgito, 2002) yaitu apek kognitif, aspek afektif, dan aspek konatif. Aspek-aspek persepsi terhadap keadilan kompensasi dapat diuraikan sebagai berikut: 1) Aspek kognitif, merupakan representasi dari apa yang dipercayai oleh individu, berisi 
kepercayaan individu mengenai apa yang berlaku atau apa yang benar bagi objek yang dipersepsi yaitu keadilan kompensasi. Aspek kognitif merupakan opini yang dimiliki individu terhadap keadilan kompensasi. Aspek ini mencakup pemikiranpemikiran dan penilaian karyawan terhadap kompensasi yang diterima yaitu gaji, insentif, dan tunjangan. 2)Aspek afektif, merupakan perasaan yang menyangkut aspek emosional subjektif dari individu terhadap objek persepsi yaitu keadilan kompensasi. Aspek afektif ini berisi perasaan memihak atau tidak memihak, mendukung atau tidak mendukung terhadap keadilan kompensasi dari perusahaan. Aspek ini mencakup perasaan-perasaan karyawan mengenai kompensasi yang diterima yaitu gaji, insentif, dan tunjangan. 3) Aspek konatif, berisi tendensi atau kecenderungan untuk bertindak atau bereaksi terhadap sesuatu objek yang dipersepsi yaitu keadilan kompensasi dengan cara tertentu. Aspek konatif menunjukkan bagaimana perilaku atau kecenderungan berperilaku yang ada dalam diri seseorang berkaitan dengan keadilan kompensasi yang diterimanya. Aspek ini mencakup kecenderungan-kecenderungan untuk berperilaku negatif atau positif yang dilakukan oleh karyawan berkaitan dengan kompensasi yang diterimanya yaitu gaji, insentif, dan tunjangan.

Prinsip teori equity yang dikembangkan oleh Adams ini adalah bahwa seseorang akan merasa puas atau tidak puas tergantung apakah orang tersebut merasakan adanya keadilan atau tidak atas suatu situasi, khususnya situasi kerja (As'ad, 2002). Menurut Rivai (2005), teori equity atau keadilan ini memiliki tiga elemen, yaitu: (1) input, (2) out comes, dan (3) comparison persons. Input atau hasil merupakan sesuatu yang berharga yang dipersepsikan karyawan memiliki kontribusi atau sumbangan terhadap pekerjaannya, seperti pendidikan, pengalaman, keahlian, jumlah tugas, dan peralatan serta perlengkapan yang dipergunakan untuk melaksanakan pekerjaan. Out comes atau hasil merupakan segala sesuatu yang berharga yang dirasakan karyawan sebagai hasil dari pekerjaannya seperti, upah atau gaji, keuntungan sampingan, simbol status, dan kesempatan untuk berkembang atau berhasil serta aktualisasi diri.
Comparison persons merupakan orang lain sebagai pembanding. Orang lain yang dijadikan pembanding bisa berasal dari organisasi atau perusahaan yang sama atau berbeda dan bisa pula dengan dirinya sendiri diwaktu lampau. Apabila orang lain yang dijadikan pembanding berasal dari perusahaan yang berbeda, maka harus ada persyaratan yang harus dipenuhi. Persyaratan yang harus dipenuhi untuk bisa membandingkan pekerjaan di antara perusahaan tersebut menurut Flippo (1984) adalah: (1) pekerjaan karyawan yang sedang diperbandingkan harus sama atau hampir sama, (2) organisasi atau perusahaan yang diperbandingkan harus serupa ukuran, misi, dan sektornya.Menurut teori ini, setiap karyawan akan membandingkan rasio input dan hasil dengan input dan hasil orang lain. Perbandingan yang dianggap seorang karyawan cukup adil maka karyawan tersebut akan merasa puas.

Apabila perbandingan tersebut tidak seimbang tetapi masih menguntungkan maka bisa menimbulkan kepuasan tetapi bisa pula tidak (misalnya pada orang yang moralis). Apabila perbandingan tersebut tidak seimbang dan merugikan maka akan menimbulkan ketidakpuasan.

$\frac{\text { Input A }}{\text { Out Comes A }}: \quad \frac{\text { Input B }}{\text { Out Comes B }}$

Gambar 1. Perbandingan input dan out comes teori keadilan

Menurut Cooper \& Makin (1995), apabila rasio input dan out comes tampak berbeda, diana seseorang merasa disepelekan atau lebih dihargai, maka orang akan berusaha mengembalikan ke keadaan yang seimbang. Apabila rasio input dan out comes tampak berbeda dimana seseorang merasa disepelekan, cara untuk mengembalikan ke keadaan seimbang dapat dilakukan dengan mengurangi produksi, kualitas atau jumlah kerjanya, demikian sebaliknya apabila seseorang merasa lebih dihargai.

Robbins (1998) berpendapat bahwa komitmen organisasi adalah sampai tingkat mana seseorang karyawan memihak pada suatu organisasi 
tertentu dan tujuan-tujuannya, dan berniat memelihara keanggotaan dalam organisasi itu. Komitmen organisasional merupakan hubungan kekuatan relatif yang luas antara individu dengan organisasi, yang karakteristiknya (Mowday et al.,1979 dalam Ritonga, 2008) meliputi; mengupayakan organisasi menjadi sukses, rasa bangga terhadap organisasi, penerimaan penugasan karena bekerja pada organisasi, pernyataan bangga karena bekerja pada organisasi, peluang dalam organisasi terhadap peningkatan kinerja, dan kepedulian terhadap masa depan organisasi.

Berdasarkan Luthan (2005), kepuasan kerja adalah hasil dari persepsi pegawai mengenai seberapa baik pekerjaan mereka memberikan hal yang dinilai penting. Misalnya, jika anggota organisasi merasa bahwa mereka bekerja terlalu keras daripada yang lain dalam depertemen, tetapi menerima penghargaan lebih sedikit, maka mereka mungkin akan memiliki sikap negatif terhadap pekerjaan, pimpinan, dan atau rekan kerja mereka. Faktor-faktor yang mempengaruhi kepuasan kerja menurut (Smith, Kendall dan Hulin dalam Munandar, 2004) terdiri dari 5 faktor diantaranya isi pekerjaan, imbalan, promosi jabatan, supervisi, rekan kerja.

\section{METODE PENELITIAN}

Penelitian ini merupakan penelitian penjelasan (eksplanatory research) yaitu penelitian menjelaskan kedudukan variabel-variabel yang diteliti serta hubungan antara satu variabel dengan variabel lain (Sugiyono, 2004). Penelitian ini dilakukan pada PT. PG Rajawali I Unit I Krebet Baru Bululawang Malang dengan populasi dalam penelitian ini adalah karyawan tetap PT. PG Rajawali I Unit I Krebet Baru Bululawang Malang yang berjumlah 528 orang. Teknik pengambilan sampel dalam penelitian ini mengunakan metode proportional random sampling karena populasi dalam penelitian ini terdiri dari golongan atau kelompok-kelompok yang sejajar (Winarsunu, 2002).

Besarnya sampel dalam penelitian ini dihitung dengan menggunakan rumus yang dikemukakan oleh Yamane (1973, dalam Supramono \& Haryanto, 2005) dan diperoleh sampel yang berjumlah 358 orang yang disajikan pada tabel 1 dibawah ini.

Tabel 1. Jumlah Sampel Penelitian Tiap Divisi

\begin{tabular}{lcc}
\hline \multicolumn{1}{c}{ Divisi } & Jumlah Populasi & Jumlah Sampel Penelitian \\
\hline Pabrikasi I & 60 & 41 \\
Instalasi I & 132 & 89 \\
Pabrikasi II & 51 & 35 \\
Instalasi II & 79 & 54 \\
Akuntansi Keuangan & 55 & 37 \\
SDM \& Umum & 40 & 27 \\
Tanaman & 111 & 75 \\
\hline \multicolumn{1}{c}{ Jumlah } & $\mathbf{5 2 8}$ & $\mathbf{3 5 8}$ \\
\hline
\end{tabular}

Untuk mendapatkan data yang relevan dengan permasalahan yang ditetapkan, maka teknik pengumpulan data yang digunakan adalah metode angket (kuesioner) dan metode wawancara. Ada 3 indikator persepsi keadilan kompensasi yang terdiri dari kognitif, afektif dan konatif (Branca, Woodworth, \& Marquis dalam Walgito, 2002). Untuk mengukur variabel persepsi keadilan kom- pensasi peneliti menggunakan instrumen yang berupa kuesioner terdiri dari empat puluh satu dengan rentang skor dalam skala ini dari 1-4. Skala ini tidak mencantumkan jawaban netral $(\mathrm{N})$ pada alternatif jawaban yang disediakan, sebab (DeVellis, 1991) mengatakan: kategori netral mempunyai arti ganda sehingga tidak dapat dinilai kecenderungannya (sesuai atau tidak sesuai), dan 
tersedianya jawaban di tengah dapat menimbulkan kecenderungan untuk memilih jawaban tengah tersebut bagi subjek yang ragu-ragu atas arah kecenderungan jawabannya.

Untuk variabel kepuasan kerja ada 5 indikator yang terdiri dari isi pekerjaan, imbalan, promosi jabatan, supervisi dan rekan kerja (Smith, Kendall dan Hulin dalam Munandar, 2004). Untuk mengukur variabel kepuasan kerja peneliti menggunakan instrumen yang berupa kuesioner terdiri dari sebelas pertanyaan dengan skala Likert 1-5.

Ada enam indikator komitmen organisasional yang terdiri dari mengupayakan organisasi menjadi sukses, rasa bangga terhadap organisasi, penerimaan penugasan karena bekerja pada organisasi, pernyataan bangga karena bekerja pada organisasi, peluang dalam organisasi terhadap peningkatan kinerja, kepedulian terhadap masa depan organisasi (Mowday et al. 1979 (dalam Ritonga,
2008). Untuk mengukur variabel komitmen organisasional peneliti menggunakan instrumen yang berupa kuesioner terdiri dari enam pertanyaan dengan skala Likert 1-5.

Dalam penelitian ini, statistik deskriptif digunakan sebagai teknik analisis dengan tujuan untuk memberikan gambaran pengiriman dan pengembalian kuesioner, gambaran umum responden penelitian (umur, jenis kelamin, tingkat pendidikan, dan lama bekerja) serta deskripsi mengenai variabel penelitian yang menunjukkan kisaran teoritis, kisaran praktis, mean dan standar deviasi.

Analisis statistik yang digunakan dalam penelitian ini adalah path analysis. Uji hipotesis dilakukan untuk mengetahui signifikan dan pengaruh dari variabel bebas terhadap variabel intervening maupun variabel terikat, serta pengaruh variabel intervening terhadap variabel terikat dengan menggunakan program SPSS for Windows versil6

Tabel 2. Profil Responden $(\mathrm{N}=200)$

\begin{tabular}{|c|c|c|c|c|}
\hline No & & Profil Demografi & Jumlah (N) & Persentase (\%) \\
\hline \multirow{3}{*}{1.} & \multirow{3}{*}{ Jenis Kelamin } & Laki-laki & 187 & 94 \\
\hline & & Perempuan & 13 & 6 \\
\hline & & $\leq 30$ th & 5 & 2 \\
\hline \multirow[t]{3}{*}{2.} & \multirow[t]{3}{*}{ Usia } & $\geq 31-40$ th & 80 & 40 \\
\hline & & $\geq 40$ th & 115 & 58 \\
\hline & & SLTP & 10 & 5 \\
\hline \multirow[t]{3}{*}{3.} & \multirow[t]{2}{*}{ Jenjang Pendidikan } & SLTA (SMA,SMEA,SMK,STM) & 136 & 68 \\
\hline & & S1 & 54 & 27 \\
\hline & \multirow{6}{*}{ Divisi } & Pabrikasi I & 20 & 10 \\
\hline \multirow{6}{*}{4.} & & Instalasi I & 45 & 23 \\
\hline & & Pabrikasi II & 10 & 5 \\
\hline & & Instalasi II & 25 & 12 \\
\hline & & Keuangan & 15 & 8 \\
\hline & & HRD dan Umum & 25 & 12 \\
\hline & \multirow{4}{*}{ Masa Kerja } & Tanaman & 60 & 30 \\
\hline \multirow[t]{3}{*}{5.} & & $\leq 5$ th & 30 & 15 \\
\hline & & $\geq 5$ th & 170 & 85 \\
\hline & & Menikah & 190 & \\
\hline 6. & Status Pernikahan & Belum Menikah & 10 & 5 \\
\hline
\end{tabular}




\section{HASIL PENELITIANDAN PEMBAHASAN}

Pada tabel 2 menunjukkan bahwa sebagian besar responden karyawan PT. PG Rajawali I Unit I Krebet Baru Bululawang Malang yang berpartisipasi dalam penelitian ini berjenis kelamin lakilaki sebanyak 187 orang (94\%) dengan usia di atas 40 tahun sebanyak 115 (58\%). Ditinjau dari tingkat pendidikan, sebagian besar responden pada karyawan PT. PG Rajawali I Unit I Krebet Baru
Bululawang Malang yang berpartisipasi dalam penelitian ini memiliki tingkat pendidikan SLTA (SMA, SMEA, SMK, STM) sebanyak 136 orang $(68 \%)$.

Berdasarkan divisi jumlah responden sebagian besar berasal dari divisi Tanaman sebanyak 60 orang (30\%), ditinjau dari masa kerja mayoritas responden bekerja diatas 5 tahun sebanyak 170 $(85 \%)$, dan berdasarkan status pernikahan sebagian besar responden sudah menikah sebanyak 190 orang $(95 \%)$.

Tabel 3. Statistik Deskriptif Variabel Penelitian

\begin{tabular}{cccccccc}
\hline & \multicolumn{3}{c}{ Teoritis } & & & \multicolumn{2}{c}{ Penelitian } \\
Variabel & N & Kisaran & Rata-rata & & Kisaran & Rata-rata & Std deviasi \\
\hline PKK & 200 & $41-164$ & 102.5 & & $85-137$ & 113.7 & 7.8 \\
KK & 200 & $11-55$ & 33.0 & & $14-55$ & 43.5 & 7.5 \\
KO & 200 & $6-36$ & 21.0 & & $6-30$ & 24.4 & 4.4 \\
\hline
\end{tabular}

Berdasarkan tabel 3 variabel persepsi keadilan kompensasi mempunyai kisaran teoritis 41 sampai dengan 164 dengan rata-rata sebesar 102,5. Pada kisaran penelitian variabel persepsi keadilan kompensasimempunyai bobot jawaban antara 85 sampai dengan 137, rata-rata (mean) sebesar 113,7 dan standar deviasi sebesar 7,8. Nilai rata-rata jawaban responden terhadap item pertanyaan konstruk persepsi keadilan kompensasi kisaran penelitian diatas rata-rata kisaran teoritis, maka dapat disimpulkan bahwa persepsikeadilan kompensasi di perusahaan responden PT. PG Rajawali I Unit I Krebet Baru Bululawang Malang sangat tinggi dan baik. Tabel 3 juga menunjukkan bahwa nilai standar deviasi untuk variabel persepsi keadilan kompensasi lebih kecil dari rata-ratanya, ini menandakan bahwa penyimpangan terhadap data adalah sangat kecil.

Variabel kepuasan kerja mempunyai kisaran teoritis bobot jawaban antara 11 sampai dengan 55 dengan rata-rata 33,0 Pada kisaran sesungguhnya, jawaban responden mempunyai bobot antara 14 sampai dengan 55 rata-rata jawaban sebesar 43,5 dengan standar deviasi 7,5. Nilai rata-rata penelitian lebih besar dari pada rata-rata teoritis dengan standar deviasi yang jauh lebih kecil dari rata-ratanya menunjukkan bahwa kepuasan kerja pada PT. PG Rajawali I Unit I Krebet Baru Bululawang Malang baik dan penyimpangan terhadap data sangat kecil.

Variabel komitmen organisasional mempunyai kisaran teoritis 6 sampai dengan 36 dengan ratarata sebesar 21,0. Pada kisaran penelitian variabel komitmen organisaional mempunyai bobot jawaban antara 6 sampai dengan 30, rata-rata sebesar 24,4 dan standar deviasi sebesar 4,4. Nilai ratarata jawaban responden terhadap item pertanyaan konstruk komitmen organisasional kisaran penelitian diatas rata-rata kisaran teoritis, maka dapat disimpulkan bahwa komitmen organisasional di PT. PG Rajawali I Unit I Krebet Baru Bululawang Malang baik. Nilai deviasi standar untuk variabel komitmen organisasional lebih kecil dari rata-ratanya, ini menandakan bahwa penyimpangan terhadap data sangat kecil.

Untuk melakukan pengujian terhadap hipotesis yang diajukan, dilakukan dengan menguji koefisien path masing-masing variabel. Koefisien path menunjukkan pengaruh langsung dari setiap variabel (Vincent Gaspers, 1992). Hasil analisis path dirangkum pada tabel 3. Dari tabel 3 dapat dilihat, nilai koefisien â dari variabel persepsi keadilan kompensasi (PKK) terhadap komitmen organisasi (KO) dan kepuasan kerja (KK) masing- 
masing sebesar 0,257 dan 0,236.Nilai koefisien â dari variabel kepuasan kerja terhadap variabel komitmen organisasional adalah sebesar 0.817.

$\mathrm{R}$ square menunjukkan besarnya pengaruh variabel independen terhadap variabel dependen, besar R square untuk persepsi keadilan kompensasi ke komitmen organisasional adalah 0,257 yang artinya hanya $25,7 \%$ pengaruh persepsi keadilan kompensasi terhadap komitmen organisasi sedangkan sisanya 74,3\% dapat dijelaskan oleh variabel lainnya. Nilai R square semakin kecil semakin tidak baik bagi model regresi karena variabel independennya tidak bisa menjelaskan variabel dependen yang lebih besar.

Tabel 4. Pengujian Koefisien

\begin{tabular}{cccccc}
\hline Model & Koefisien $\boldsymbol{\beta}$ & $\mathbf{t}$ & R Square & $\boldsymbol{P}$ & Keterangan \\
\hline PKK--- KO & 0.257 & 3.737 & 0.066 & .000 & Signifikan \\
PKK--- KK & 0.236 & 3.416 & 0.056 & .001 & Signifikan \\
KK--- KO & 0.817 & 19,902 & 0,667 & .000 & Signifikan \\
\hline
\end{tabular}

Untuk menjelaskan pengaruh masing-masing variabel baik pengaruh langsung maupun pengaruh tidak langsung dapat dijelaskan pada tabel 5. Dari tabel 5 didapat pengujian secara langsung untuk pengujian koefisien jalur antara persepsi keadilan kompensasi terhadap komitmen organisasional adalah persepsi keadilan kompensasi berpengaruh secara langsung terhadap komitmen organisasional sebesar 25,7 \%; pengujian koefisien jalur antara persepsi keadilan kompensasi terhadap kepuasan kerja adalah persepsi keadilan kompensasi berpengaruh secara langsung terhadap kepuasan kerja sebesar 23,6\%; sedangkan pengujian koefisien jalur antara kepuasan kerja terhadap komitmen organisasional adalah kepuasan kerja berpengaruh secara langsung terhadap komitmen organisasional sebesar $81 \%$.

Tabel 5. Pengaruh Langsung dan Tidak Langsung

\begin{tabular}{lcl}
\hline \multicolumn{1}{c}{ Model } & Koefisien $\boldsymbol{\beta}$ & \multicolumn{1}{c}{ Keterangan } \\
\hline PKK--- KO & 0,257 & Pengaruh Langsung \\
PKK--- KK & 0,236 & Pengaruh Langsung \\
KK--- KO & 0,817 & Pengaruh Langsung \\
PKK---KK---KO & 0,193 & Pengaruh Tidak Langsung \\
\hline
\end{tabular}

Pengujian koefisien jalur pengaruh tidak langsung antara persepsi keadilan kompensasi terhadap komitmen organisasional melalui kepuasan kerja sebesar 0,193 atau 19,3\%; nilai tersebut dihitung dari hasil perkalian koefisien $\beta$
$(\mathrm{PKK}-\mathrm{KK}=0,236)$ dengan koefisien â $(\mathrm{KK}-$ $\mathrm{KO}=0,817)$. Hal ini menunjukkan bahwa kepuasan kerja dapat berfungsi sebagai variabel mediasi antara persepsi keadilan kompensasi terhadap komitmen organisasional.

Tabel 6. Perbandingan Pengaruh Langsung dan Pengaruh Tidak Langsung

\begin{tabular}{ccc}
\hline Model & Pengaruh Langsung & Pengaruh Tidak Langsung \\
\hline PKK--- KO & 0,257 & - \\
PKK--- KK & 0,236 & - \\
KK--- KO & 0,817 & - \\
PKK---KO & - & 0,193 \\
& & Melalui KK \\
\hline
\end{tabular}


Tabel 6 Menunjukkan bahwa pengaruh persepsi keadilan kompensasi terhadap komitmen organisasional, persepsi keadilan kompensasi terhadap kepuasan kerja, dan kepuasan kerja terhadap komitmen organisasional menunjukkan nilai sebesar pengaruh langsungnya karena tidak ada hubungan lain yang dapat mempengaruhi kekuatan tiap-tiap hubungan tersebut. Koefisien â pengaruh kepuasan kerja terhadap komitmen organisasional memiliki nilai yang paling besar.

Tabel 6 juga menunjukkan bahwa pengaruh tak langsung persepsi keadilan kompensasi terhadap komitmen organisasional melalui kepuasan kerja sebesar 0,193.Nilai ini lebih kecil dibandingkan dengan nilai pengaruh langsung persepsi keadilan kompensasi terhadap komitmen organisasional sebesar 0,257 . Sehingga persepsi keadilan kompensasi akan memiliki pengaruh yang lebih kuat dengan komitmen organisasional jika hubungan tersebut bersifat langsung dari pada jika hubungan tersebut bersifat tak langsung dengan kepuasan kerja sebagai variabel mediasi.

Pengujian terhadap hipotesis satu dalam penelitian ini menyatakan bahwa terdapat pengaruh antara antara persepsi keadilan kompensasi terhadap komitmen organisasional. Hal tersebut mendukung hasil penelitian Inverson Roy (1994, dalam Roberts, Coulson, 1999) yang menghubungkan keadilan eksternal dengan komitmen organisasional. Mereka merasa bahwa karyawan yang merasa diperlakukan adil maka akan diidentifikasikan dan terlibat dalam organisasi dan hal itu mempunyai loyalitas yang lebih tinggi terhadap organisasi.

Selain itu keadilan prosedural internal akan secara positif berpengaruh terhadap komitmen organisaional, maka jika perusahaan menaati aturan-aturan yang berlaku didalam perusahaan maka karyawan akan merasa bahwa dirinya akan diperhatikan perusahaan terutama dalam pemberian bonus atau tunjangan sehingga mereka merasa bahwa perusahaan seperti bagian keluarga. Seperti yang diungkapkan oleh Firman selaku Karyawan Staf Divsi HRD:

"Jika karyawan menerima hasil sesuai dengan yang didapatkan rekan kerjanya (tidak ada perbedaan dalam pemberian gaji pokok dan perhitungan bonus sesuai dengan jumlah yang dihasilkan), tentunya karyawan akan berorientasi membantu organisasi ini untuk mencapai targetnya menjadikan pabrik gula krebet sebagai pabrik yang unggul dibandingkan pabrik gula lainnya dengan kwalitas/mutu gula yang baik" (Wawancara 12 Desember 2011).

Pengujian terhadap hipotesis dua dalam penelitian ini yang menyatakan bahwa terdapat pengaruh antara persepsi keadilan kompensasi terhadap kepuasan kerja ternyata terbukti menunjukkan adanya pengaruh persepsi keadilan kompensasi terhadap kepuasan kerja dengan tingkat signifikansi $<0,05(\mathrm{p}=0,001)$, ini menunjukkan hipotesis dua dapat diterima. Kondisi tersebut berarti bahwa semakin positif persepsi karyawan terhadap keadilan kompensasi maka akan semakin tinggi kepuasan kerjanya.

Berdasarkan hasil penelitian tersebut dapat diketahui bahwa, persepsi terhadap keadilan kompensasi merupakan salah satu faktor yang dapat mempengaruhi kepuasan kerja karyawan. Pendapat senada juga dikemukakan dalam teori keadilan dari Adam yang dikutip oleh Rivai (2005) yaitu, setiap karyawan akan membandingkan rasio input dan out comes yang diterimanya serta membandingkan out comes yang diterimanya dengan out comes dari comparison persons. Apabila tercapai perimbangan antara input dan out comes serta comparison persons maka out comes bisa dikatakan adil.

Karyawan akan memiliki persepsi terhadap keadilan kompensasi yang positif apabila rasio input dan output seimbang sehingga akan memiliki kepuasan kerja yang bagus. Apabila imbalan yang diterima karyawan dipersepsikan terlalu besar atau terlalu kecil maka karyawan akan memiliki persepsi terhadap keadilan kompensasi yang negatif sehingga bisa mengalami distres atau ketidakpuasan. Seperti yang diungkapkan oleh Matius selaku Ketua Umum Serikat Pekerja Rajawali I:

"Dalam pemberian kompensasi PT. PG Rajawali I Unit I Krebet Baru Bululawang sudah sesuai dengan aturan yg berlaku yaitu yang tercantum pada Perjanjian Kerja Ber- 
sama dimana semua hak-hak karyawan sudah diatur dan sudah dilaksanakan dengan baik. Sehingga dalam kurun waktu 5 tahun ini tidak ada karyawan yang mengundurkan diri, kecuali karyawan tersebut bermasalah. Hal ini bisa dijadikan indikator bahwa karyawan merasa puas bekerja pada PT. PG Rajawali I Unit I Krebet Baru Bululawang” (Wawancara 13 Desember 2011).

Pengujian terhadap hipotesis tiga dalam penelitian ini yang menyatakan bahwa terdapat pengaruh antara kepuasan kerja dengan komitmen organisasional ternyata terbukti, artinya bahwa kepuasan kerja berpengaruh terhadap komitmen organisasional sehingga semakin meningkatnya faktor kepuasan kerja maka akan meningkatkan pengaruh terhadap komitmen organisasi.

McNeese-Smith (1996) menunjukkan hubungan antara kepuasan kerja dan komitmen organisasi, dalam penelitiannya kepuasan kerja dan komitmen organisasi merupakan variabel independen yang berpengaruh signifikan dan positif terhadap sikap manajemen terhadap strategi perusahaan yang tercermin melalui kinerja karyawan. Elangovan (2001) dalam penelitiannya menemukan hubungan yang kuat antara kepuasan kerja dengan komitmen organisasional mempunyai hubungan positif.

"Hal itu juga dipertegas penjelasan Budi selaku Karyawan Staf Divisi Umum PT. PG Rajawali I Unit I Krebet Baru Bululawang Malang "Pimpinan memberikan kesempatan pada karyawan untuk bisa mengapresiasikan dirinya jika berprestasi akan mendapatkan penghargaan. Promosi jabatan sudah dilakukan sesuai dengan aturan yang ada. Selain itu untuk memotivasi karyawan supaya tidak merasa jenuh dalam bekerja maka diadakan rekreasi bersama. Karyawan mampu bekerja sama dengan baik, merasa tenang, nyaman, tidak ada gejolak dalam bekerja maka hal ini sangat membantu penyelesaian tugas-tugas yang diberikan dapat diselesaikan dengan tepat waktu sehingga meningkatkan pada hasil output yang baik berupa produktivias karyawan yang berdampak juga pada keuntungan perusahaan baik secara langsung maupun tidak langsung “(Wawancara, 12 Desember 2011).

Pengaruh tidak langsung persepsi keadilan kompensasi terhadap komitmen organisasional melalui kepuasan kerja lebih kecil dibandingkan dengan pengaruh langsung antara persepsi keadilan kompensasi terhadap komitmen organisasional, hal ini mengindikasikan bahwa untuk meningkatkan komitmen organisasi PT. PG Rajawali I Unit I Krebet Baru Bululawang Malang maka pihak manajemen perlu meningkatkan persepsi karyawan mengenai keadilan kompensasi. Artinya bahwa karyawan tetap pada PT. PG Rajawali I Unit I Krebet Baru Bululawang Malang tidak mementingkankan tingkat kepuasan kerja, tetapi karyawan merasa dengan pemberian kompensasi yang adil dari perusahaan maka lebih meningkatkan komitmen karyawan terhadap organisasinya.

Hal ini dapat dilihat dari data responden bahwa karyawan pada PT. PG Rajawali I Unit I Krebet Baru Bululawang Malang dari tingkat usia mayoritas karyawan berusia lebih dari 40 tahun sebanyak 115 orang $(58 \%)$ dan dengan masa kerja lebih dari lima tahun sebanyak 170 orang (85\%), maka dapat disimpulkan bahwa mayoritas karyawan PT. PG Rajawali I Unit I Krebet Baru Bululawang Malang adalah karyawan yang mempunyai tingkat loyalitas yang tinggi terhadap perusahaannya sehingga tidak mementingkan tingkat kepuasan kerja.

\section{SIMPULAN}

Dari hasil pengujian disimpulkan bahwa persepsi keadilan kompensasi berpengaruh positif dan signifikan terhadap komitmen organisasional, persepsi keadilan kompensasi berpengaruh positif dan signifikan terhadap kepuasan kerja, kepuasan kerja berpengaruh positif dan signifikan terhadap komitmen organisasional dan mempunyai pengaruh langsung terbesar dibandingkan pengaruh langsung variabel lainnya. Persepsi keadilan kompensasi memiliki pengaruh yang lebih kuat terhadap komitmen 
organisasional jika hubungan tersebut bersifat langsung dari pada pengaruh tersebut bersifat tidak langsung dengan kepuasan kerja sebagai variabel mediasi. Karyawan tetap pada PT. PG Rajawali I Unit I Krebet Baru Bululawang Malang tidak mementingkankan tingkat kepuasan kerja, tetapi karyawan merasa dengan pemberian kompensasi yang adil dari perusahaan maka lebih meningkatkan komitmen karyawan terhadap organisasinya.

\section{DAFTAR PUSTAKA}

As'ad, Muh. (2002). Seri Ilmu Sumber Daya Manusia: Psikologi Industri, Yogyakarta: Liberty

Babakus, Emin, David W Cravens, Mark Johnston dan Wiliam C Moncrief (1993). "Examining The Role of Organizational Variables in The Salesperson Job Satisfaction Model, "Journal Of Personal Selling \& SalesManagement Journal, Vol.XVI, No.3

Elangovan, AR. (2001). "Causal Ordering of Stress, Satisfaction and Commitment and Intention to Quit: a Structural Equation Analysis, "Leadership \& Organization Development Journal, Vol.22, No.4. pp.159165

Flippo, Edwin B. (1984). Personnel Psychology. 6th Edition, Singapore: McGraw Hill Cooper Cary L. \& Makin, P. 1995. Psikologi Untuk Kelompok Profesional dan Psikologi Untuk Manajer, Jakarta.:Arcan

James A. Robert, Kevin R. Coulson, Lawrence B. Chonko, (1999). "Salesperson Perception of equity and Justice and their Impact on Organizational Comitment and Intent Turnover", Journal of Marketing, Vol.20, No 2

Luthans, F. (2005).Organization Behavior. New York: McGraw Hill International

Munandar, Ashar S. (2004). Psikologi Industri dan Organisasi. Jakarta: Penerbit Universitas Indonesia.

Rakhmat, Jalaluddin. (1998). Psikologi Komunikasi. Bandung: PT Remaja Rosdakarya

Ritonga, Panangaran (2008). Pengaruh Budaya Paternalistik dan Komitmen Organisasi terhadap Hubungan Antara Partisipasi Anggaran dan Kinerja Manajerial pada PDAM Tirtanadi Propinsi Sumatera Utara. Tesis Pascasarjana Universitas Sumatera Utara, Medan.

Rivai, H. Veithzal. (2005). Manajemen Sumber Daya Manusia Untuk Perusahaan: Dari Teori Ke Praktek. Jakarta: PT Raja Grafindo Persada

Robbins, P. Stephen. (1998). Perilaku Organisasi: Konsep, kontroversi, aplikasi. Jilid 1. Jakarta: PT Prenhallindo

Sudarwanti Retnaningsih. (2007). Analisis Pengaruh keadilan kompensasi, Peran kepemimpinan, dan kepuasan kerja Terhadap komitmen organisasi dalam Meningkatkan Kinerja Karyawan (Studi Kasus: Pada Sentral Pengolahan Pos Semarang). Tesis. Semarang: Program Magister Manajemen Universitas Diponegoro

Sugiyono.(2004). Statistik untuk penelitian. Bandung: Alfabeta

Suhartini.(1999). Keadilan Dalam Pemberian Kompensasi. Fakultas ekonomiUniversitas Islam Indonesia. Jurnal Siasat Bisnis HUMAN RESOURCES

Supramono \& Haryanto, J.O. (2005). Desain Proposal Penelitian Studi Pemasaran. Yogyakarta.Andi.

Walgito, Bimo. (2002). Pengantar Psikologi Umum. Yogyakarta: Andi Offset

Winarsunu, T. (2004).Statistik dalam penelitian psikologi dan pendidikan.Universitas Muhamadiyah: Malang

Witt, L. Alan. \& Nye, Lendell G. (1992).Gender and the Relationship Between Perceived Fairness of Pay or Promotion and Job Satisfaction. Journal of Applied Psychology. Vol. 77

Daftar Karyawan Tetap. November 2011. PT.PG.Rajawali I Unit PG Krebet Baru Malang

PT. PG. Rajawali I Unit PG.Krebet Baru. (200112013). Perjanjian Kerja Bersama PT.PG.Rajawali I Unit PG Krebet Baru Malang. 